\title{
AGT wt Allele
}

National Cancer Institute

\section{Source}

National Cancer Institute. AGT wt Allele. NCI Thesaurus. Code C52390.

Human AGT wild-type allele is located within 1q42-q43 and is approximately $12 \mathrm{~kb}$ in length. This allele, which encodes angiotensinogen protein, plays a role in the modulation of blood pressure. Mutations in the gene may increase the risk of essential hypertension, renal failure and preeclampsia. 